\title{
UNESCO AND UNICEF ACTIVITIES FOR THE RIGHTS OF INDIGENOUS CHILDREN
}

\author{
Anita Rakhman $^{1^{*}}$ and Naser Abdel Raheem Al Ali ${ }^{2}$ \\ ${ }^{1}$ Postgraduate at the International law department of the Law Institute, RUDN University, Russia, \\ 1042190143@pfur.ru \\ ${ }^{2} \mathrm{PhD}$ in Marine Law Dept. of Law Institute at RUT (MIIT), Russia, drnasernimer@yahoo.com \\ ${ }^{*}$ Corresponding Author
}

\begin{abstract}
Over the past few decades, protecting indigenous peoples' rights has increased attention at the universal and regional, and national levels. The issue of protecting indigenous children's rights as a vulnerable category of persons is particularly acute due to environmental change, displacement, economic exclusion, exploitation, or armed conflict.

It is related, inter alia, to exercising the right to education, access to health services, cultural identity, protection from exploitation, abuse, discrimination, and violence. Representatives of the indigenous population are the custodians of unique knowledge and various languages, which are significant elements of humanity's heritage. An international legal framework and various international and regional mechanisms have been established to promote and protect indigenous children's rights and fundamental freedoms.

The universal human rights protection system pays special attention to the indigenous population's rights since its representatives have been subjected to persecution, mass destruction, and territories - to the illegal seizure of colonialists for many centuries. However, over the past decades, significant progress can be seen in helping vulnerable groups of indigenous peoples (women, children, the elderly, people with disabilities) to implement their legal rights. In this regard, in this article, we will consider what measures are being taken by the United Nations Specialized Agency for Education, Science and Culture (UNESCO) and the United Nations Children's Fund (UNICEF) to support Aboriginal children.
\end{abstract}

Keywords: Aboriginal children, UNICEF, UNESCO, Indigenous people.

\section{INTRODUCTION}

The United Nations Educational, Scientific and Cultural Organization (UNESCO) is an international organization with the status of a specialized agency of the United Nations. It seeks to establish universal peace by establishing interstate cooperation in culture, science, and education. Its activity is based on the promotion of intercultural communication, the moral solidarity of humanity. According to document $37 \mathrm{C} / 4$ (Medium-Term Strategy 2014-2021), the Organization promotes and will further promote the implementation of the world's indigenous peoples' rights, recognizing the importance of their traditional systems of consciousness.

\section{METHODOLOGY}

Published in 2018, the UNESCO Policy on Indigenous Peoples report recalls the importance of eliminating discrimination and marginalization of the indigenous population associated with remoteness to educational institutions, the need to work from an early age, lack of electricity and Internet access, lack of understanding 
of the state language, complicated peer relationships due to cultural differences. Special attention in the document is paid to girls from among the indigenous peoples, who are burdened with household duties and younger sibyls' upbringing.

We also note several provisions of the UNESCO Salaman Declaration and the Framework for Action on Education for Persons with Special Needs, adopted in 1994 by the World Conference on Education for Persons with Special Needs. Art. 2 of the Declaration emphasizes the uniqueness of each child and Art. 3 calls on national governments to pay attention to improving education systems that can reach all children, regardless of individual differences. In Art. 3 The Framework for Action proclaims the guiding principle that schools should accept all children regardless of physical, social, linguistic, cultural, or other characteristics, including indigenous and nomadic children.

Based on this provision, in 2009, the Organization formulated Policy Guidelines for Inclusive Education, the essence of calling on national governments to provide quality education for all categories of people, including Aboriginal people.

If we talk about the international legal protection of indigenous children within the framework of international intergovernmental organizations, it is also necessary to pay attention to the United Nations Children's Fund (UNICEF).

All UNICEF documents emphasize that the mission of the Organization is to ensure the protection of the lives of children, help in realizing their rights, and help them unlock their potential from infancy to adulthood. UNICEF's policy is to work with numerous partners around the world to empower the protection of every child, without exception. The final reports on the Organization's critical areas of activity provide a detailed description of the measures taken by it.

\section{RESULTS}

UNESCO implements long-term programs to support indigenous children's education in the Philippines, Australia, Bolivia, Mexico, USA, Nepal, Morocco, Guatemala, New Zealand.

The Organization implements several multimedia programs to educate children of indigenous peoples using traditional cultural elements to preserve it for the younger generations. For example, there are already digital lessons on the history and skills of canoeing for children of the indigenous peoples of Polynesia, the use and maintenance of the sustainability of forest ecosystems for the children of the Marovo people in the Solomon Islands, the preservation of the biosphere for the children of the Majagna people from Nicaragua, the traditional handling of natural resources for aborigine children of Vanuatu and Canada.

Overall, as highlighted in the 2017 Guide to Inclusiveness and Equality in Education, the 21st century has seen significant progress towards realizing the right to quality education. However, there are still 263 million children aged 6-17, of which the lion's share is occupied by indigenous children who do not have the opportunity to attend school. Therefore, one of UNESCO's essential areas is combating marginalization and inequality within indigenous communities, linguistic and ethnic minorities.

UNICEF's work is divided into several areas, corresponding to aspects of children's lives that are essential for their well-being:

1. Every child's life should be full-fledged. To reduce the number of children suffering from hunger, the Organization is active, especially among the most vulnerable category - the indigenous population. For example, after carefully examining the nutritional needs and concerns of children under five years of age from the Yanomami tribe in Brazil, together with the Osvaldo Cruz Foundation, UNICEF formulated some useful recommendations for the country's Ministry of Health aimed at improving the nutritional system of indigenous children.

2. Every child must learn. The Organization implements measures to support national authorities in providing quality education to Aboriginal children. For example, the 2015-2018 program provided to the governments of Cambodia and Myanmar, consisting of many ethnocultural events, contributed to the popularization of the culture of indigenous tribes, the publication of 25 children's books in the languages of indigenous communities with a circulation of 415,000 copies. In 7 states of Myanmar, 20,000 primary school children got the opportunity to work with textbooks in their native language. In 2019, UNICEF developed a bilingual education model for the education system in 3 regions of Peru, taking full responsibility for all technical equipment. As part of the campaign, bilingual round tables were regularly held with representatives of the indigenous population of various professions (writers, philologists, and others), which was the impetus for creating many bilingual education programs in these areas. 
3. Every child must be protected from abuse and exploitation. In this context, it is emphasized that children from indigenous communities, who may be exposed to the slave trade, sexual violence, and the complication of living conditions during armed conflict, deserve extra attention. In this regard, the Strategic Plan 20182021 developed by UNICEF sees one of the tasks to carefully work directly within the tribes and study in detail their way of life to increase the level of mutual understanding and the possibility of providing appropriate assistance in the event of a potential threat of this nature.

4. Every child's life should be in a safe and healthy environment. As the Organization notes, it is essential to maintain social and economic resilience in the light of current developments in climate change and weather events. UNICEF has formed the so-called "Nawe Nuze" (Solidarity Groups) in Burundi, based on the values of children's lives and loyalty to indigenous communities, made up of volunteers to raise donations and improve the quality of life of the tribes. Now there are 500 "groups" in 18 regions of the country, and one in 30 volunteers is a representative of the aboriginal population under 18 years of age.

5. All children are equal, and each of them has the right to life. To reduce as much as possible the number of indigenous children living below the poverty line and, therefore, lacking adequate social and economic conditions to lead a meaningful life, UNICEF is developing recommendations for national governments. For example, an Alternative Learning System program was implemented in one of the Philippine provinces, in which 130 volunteers were trained to educate Aboriginal children who had no access to school. About 2,700 children have received education according to this model because they have acquired scientific, social, household, and other skills. In 2019, on the recommendation of the Organization and the support of the state government, 39,102 indigenous teenagers in Brazil were able to receive special training with a political and legal bias to be able to participate in the country's activities in the future, defending the rights of indigenous people.

\section{DISCUSSIONS}

Many international human rights experts argue that UNESCO and UNICEF are indeed making serious efforts to improve Aboriginal children's living standards. Organizations, through a variety of strategies and programs, as well as financial support, allow children to try to fulfill themselves from different sides while focusing on acute global problems that affect their well-being and the communities: climate change, human trafficking, sexual slavery, forced displacement, extreme poverty, and others.

\section{ACKNOWLEDGEMENT}

This article has been prepared under the RUDN university 5-100 program.

\section{REFERENCE LIST}

Medium-term strategy for 2014-2021. (2014) UNESCO. France. URL: https://unesdoc.unesco.org/ark:/48223/pf0000227860_rus

UNESCO Policy on Engaging with Indigenous Peoples. (2018) UNESCO. URL: https://unesdoc.unesco.org/ark:/48223/pf0000262748

Salaman Declaration and Framework for Action on Education for Persons with Special Needs. (1994) UNESCO. URL: https://unesdoc.unesco.org/ark:/48223/pf0000098427_rus

Guidelines for Inclusive Education. (2009) UNESCO. URL: https://docplayer.ru/27371659-Rukovodyashchieprincipy-politiki-v-oblasti-inklyuzivnogo-obrazovaniya.html

UNESCO. Official website. URL: http://www.unesco.org/new/en/natural-sciences/priorityareas/links/knowledge-transmission/

A Guide for ensuring inclusion and equity in education. UNESCO. 2017. URL: https://unesdoc.unesco.org/ark:/48223/pf0000248254

UNICEF. Official website. URL: https://www.unicef.org/what-we-do

Global Annual Results Reports 2019. UNESCO. 2020. URL: https://www.unicef.org/reports/global-annualresults-2019 